\title{
Studi Kelayakan Pengembangan PTC Indrapura Menjadi RSU Indrapura Dengan Pendekatan Analisis Kecenderungan (Analisis SWOT)
}

\author{
Daniel Ginting ${ }^{1}$, Nina Fentiana ${ }^{2^{*}}$ \\ ${ }^{1}$ Pascasarjana, Universitas Sari Mutiara Indonesia, Jl.Kapten Muslin No 79 Medan \\ ${ }^{2}$ FFIKes, Universitas Sari Mutiara Indonesia \\ *Correspondence email: fentiana.nina@gmail.com
}

\begin{abstract}
Abstrak. Provincial Training Centre (PTC) Indrapura di Sipare-pare Kecamatan Air Putih Kabupaten Batubara sebelumnya adalah sarana pendidikan bagi calon dokter, perawat dan bidan dari berbagai daerah di Sumatera Utara. Sejak tahun 2017 PTC Indrapura menjadi UPT RSU Indrapura. Pemerintah Provinsi Sumatera Utara merencanakan UPT RSU Indrapura beroperasi secara penuh menjadi Rumah Sakit kelas C berdasarkan SK Kepala Dinas Kesehatan Provinsi Nomor: 441/ 10465/ 2017 tertanggal 3 Mei 2017. Perencanaan UPT RSU Indrapura mempunyai dampak positif bagi masyarakat yang berada di Kabupaten Batubara. Untuk ini diperlukan suatu studi kelayakan untuk menghindari suatu investasi yang sia-sia karena investasi yang dilaksanakan bisa berbeda dengan keinginan dan kebutuhan masyarakat. Analisis data menggunakan data sekunder, studi kepustakaan dan pengamatan lapangan. Hasil diagram kelayakan adalah Kuadran I : $\mathrm{SO}=3,8$ x 1,8 = 6,84; Kuadran II: WO = $2,4 \mathrm{x} 1,8=4,32 ;$ Kuadran III : ST $=3,8$ × 2,5 = 9,50; Kuadran IV : WT $=2,4$ × 2,5 = 6. Fakta diatas menunjukkan bahwa UPT RSU indrapura berada di Kuadran 111 hal ini berarti: UPT RSU Indrapura layak dikembangkan, Dengan rekomendasi memperkuat kekuatan dan mendapatkan peluang.
\end{abstract}

Kata kunci: Kelayakan; Kecenderungan; Rumah sakit; PTC

\begin{abstract}
The Indrapura Provincial Training Center (PTC) in Sipare-pare, Air Putih District, Batubara Regency was previously an educational facility for prospective doctors, nurses and midwives from various regions in North Sumatra. Since 2017 PTC Indrapura has been the UPT of Indrapura Hospital. The North Sumatra Provincial Government plans the UPT Indrapura Hospital to fully operate into a class C hospital based on the Decree of the Head of the Provincial Health Office Number: 441/10465/2017 dated 3 May 2017. The planning of the UPT Indrapura Hospital has a positive impact on the people in Batubara Regency. For this, a feasibility study is needed to avoid a wasted investment because the investment carried out can be different from the wants and needs of the community. Data analysis using secondary data, library research and field observations. The results of the feasibility diagram are Quadrant I: $S O=3.8 \times 1.8=6.84$; Quadrant II: $W O=2.4 \times 1.8=4.32$; Quadrant III: $S T=$ $3.8 \times 2.5=9.50$; Quadrant IV: WT =2,4 x 2,5 = 6. The above facts show that the UPT Indrapura Hospital is in Quadrant III this means: The UPT Indrapura Hospital is feasible to be developed, with recommendations to strengthen strength and get opportunities.
\end{abstract}

Keywords: Eligibility; Trend; Hospital; PTC

\section{PENDAHULUAN}

Pembangunan yang dilakukan di segala bidang selain membawa pertumbuhan yang cepat juga mengakibatkan terjadinya perubahan pada lingkungan, pola hidup masyarakat dan juga pada pemanfaatan pelayanan kesehatan (Alamsyah, 2011). Provincial Training Centre (PTC) Indrapura di Sipare-pare Kecamatan Air Putih Kabupaten Batubara sebelumnya adalah sarana pendidikan bagi calon dokter, perawat dan bidan dari berbagai daerah di Sumatera Utara. Sejak tahun 2017 PTC Indrapura menjadi UPT RSU Indrapura.

UPT. RSU Indrapura mempunyai tugas membantu Kepala Dinas Kesehatan dalam menyelenggarakan urusan pemerintahan dalam pelayanan pengobatan, perawatan, rehabilitasi dan pemulihan kesehatan masyarakat sesuai standar yang ditentukan, pemenuhan standar mutu fasilitas penunjang medik dan keperawatan rumah sakit serta pembinaan, pengendalian, pencegahan dan promosi kesehatan masyarakat tingkat Provinsi.
Pemerintah Provinsi Sumatera Utara merencanakan UPT RSU Indrapura beroperasi secara penuh menjadi Rumah Sakit kelas C berdasarkan SK Kepala Dinas Kesehatan Provinsi Nomor: 441/ 10465/ 2017 tertanggal 3 Mei 2017. Perencanaan UPT RSU Indrapura mempunyai dampak positif bagi masyarakat yang berada di Kabupaten Batubara.

Untuk ini diperlukan suatu studi kelayakan untuk menghindari suatu investasi yang sia-sia karena investasi yang dilaksanakan bisa berbeda dengan keinginan dan kebutuhan masyarakat. Studi kelayakan meneliti perubahan lingkungan, kebutuhan pasar dan perhitungan investasi untuk mengantisipasi, diharapkan hasil studi kelayakan dapat membantu Pemerintah Provinsi Sumatera Utara dan pengelola mengambil kebijakan yang tepat dan mampu berkembang, memberikan pelayanan yang maksimal kepada seluruh masyarakat dengan memanfaatkan teknologi yang tersedia sehingga pada akhirnya dapat meningkatkan derajat kesehatan masyarakat Kabupaten Batu Bara. 
Daniel Ginting dan Nina Fentiana, Studi Kelayakan Pengembangan PTC Indrapura Menjadi RSU Indrapura Dengan

\section{METODE}

Metode penyusunan Studi Kelayakan UPT RSU Indrapura berdasar pada metode pengumpulan dan analisis data yang juga digunakan pada studi sejenis (LPPM, 1994):

1. Data Sekunder

Data ini diperoleh dari berbagai sumber seperti Dinas Kesehatan Kabupaten Batu Bara, BPS Kabupaten Batu Bara dan instansi terkait lainnya. Data-data ini dapat berupa data statistik kesehatan maupun data pendukung lain.

2. Studi Kepustakaan

Studi kepustakaan menghimpun informasi yang relevan dengan studi kelayakan sebagai pembanding studi ini, berbagai referensi pustaka yang mendukung akan digunakan dalam koridor studi kelayakan ini .

3. Pengamatan Lingkungan

Agar lebih meyakinkan berbagai informasi yang diperoleh, selanjutnya diadakan peninjauan langsung ke lokasi dan sekitarnya (Meriam \& Kraige, 1988).

\section{HASIL DAN PEMBAHASAN}

Analisis fakta yang dilakukan terhadap UPT RSU Indrapura melalui proses sebagai berikut (Rangkuti, 2013):

1. Melakukan indentifikasi isu Strategis kesehatan di Kabupaten Batu Bara pada umumnya dan Kecamatan Air Putih pada khususnya dan menuangkannya dalam Analisa SWOT (Strenght, weakness, opurtunity, threat)

2. Mendiskusikan isu kecenderungan yang akan dihadapi oleh UPT RSU Indrapura dimasa yang akan datang

3. Menilai kelayakan UPT RSU Indrapura

Analisis fakta UPT RSU Indrapura diuraikan dalam bentuk Kekuatan (Strenght), kelemahan (weakness), peluang (oppurtunity) dan ancaman (threats). adapun hal ini diuraikan sebagai berikut:

\section{Kekuatan (Strenght) \\ Letak dan Geografi}

Letak dan geografi UPT RSU Indrapura berada pada lokasi strategis di jalan lintas sumatera, dilalui oleh masyarakat dari berbagai kota menuju ibu kota Provinsi Sumatera Utara.

\section{Demografi Kecamatan Air Putih}

Jumlah penduduk di kecamatan Air Putih setiap tahun bertambah tahun 2017 berjumlah 50,847 jiwa. Kelompok umur terbesar adalah kelompok umur bayi dan usia produktif.

\section{Demografi Kabupaten Batu Bara}

Laju pertumbuhan penduduk mencapai $1,17 \%$ pertahun, saat ini Sebesar 409.091 jiwa. Kelompok usia terbesar adalah kelompok bayi/anak, dan kelompok usia produktif

\section{Kondisi eksisting UPT RSU indrapura}

Kondisi eksisiting lahan UPT RSU Indrapura cukup baik karena pencapaian ke Lokasi mudah dan situasi lokasi memenuhi persyaratan perundang undangan.

\section{Kondisi Bangunan}

UPT RSU Indrapura sudah memiliki ruangan pelayanan rumah sakit setara kelas C. (E, 2006) (Kementrian Kesehatan Republik Indonesia, 2012) (Jakfar, 2012) (Sofyan, 2003) (Sutojo, 2002)

\section{Kondisi Utilitas}

Secara umum jaringan utilitas yang ada di UPT RSU Indrapura sudah cukup memadai

\section{Kondisi SDM UPT RSU Indarapura}

SDM di UPT RSU Indrapura sudah layak sesuai dengan SDM minimal Permenkes No 56 Tahun 2014.

\section{Kondisi peralatan sudah mendukung pelayanan \\ Pertimbangan dari segi hukum dan perundang- undangan}

UPT RSU Indrapura sudah memenuhi persyaratan lokasi, bangunan, prasarana, sumber daya manusia, kefarmasian, dan peralatan.

\section{Peserta BPJS}

Jumlah peserta BPJS di Kabupaten Batu bara adalah 67502 yang terdiri dari 20372 Non PBI, 6575 PBI APBD, dan PBI APBN 40555.

\section{Kelemahan (Weakness) BPJS}

Persentasi penduduk peserta BPJS masih rendah. Penduduk Kabupaten Batubara berjumlah 409.091 jiwa, peserta BPJS sejumlah 67502 jiwa, atau 16,5\% dari total penduduk.

\section{SDM UPT RSU Indrapura}

Kelemahan SDM di UPT RSU Indrapura terletak pada jumlah Bidan dan perawat. Jumlah perawat yang dibutuhkan sebesar 1 tempat tidur berbanding 1,5 jumlah perawat.

\section{Situasi Bangunan}

Bangunan yang sedang direhab dan dibangun baru sedang berjalan, kelemahannya adalah lapangan parkir yang tersedia. Asumsi perhitungan kebutuhan lahan parkir pada rumah sakit idealnya adalah $37,5 \mathrm{~m} 2$ s/d 50m2 per tempat tidur (sudah termasuk jalur sirkulasi kendaraan) 
Daniel Ginting dan Nina Fentiana, Studi Kelayakan Pengembangan PTC Indrapura Menjadi RSU Indrapura Dengan Pendekatan Analisis Kecenderungan (Analisis SWOT)

\section{Ruang Hijau}

Daerah penghijauan dan pertamanan masih minimal dan perlu diperluas

\section{Pengembangan bangunan}

Perhitungan perkiraan kebutuhan total luas lantai bangunan untuk rumah sakit umum kelas $\mathrm{C}$ minimal 60 $\mathrm{m} 2 /$ tempat tidur.

\section{Garis Kemiskinan Di Kabupaten Batu Bara}

Angka kemiskinan di Kabupaten Batu Bara mengalami peningkatan. Pada tahun 2012 sebesar $11,24 \%$ meningkat menjadi $12,48 \%$ di tahun 2017.

\section{Peluang (Opportunity) \\ Jumlah Kelahiran}

Jumlah kelahiran di Kabupaten Batu bara di tahun 2017 meningkat menjadi 9201 kelahiran. Pelayanan yang baik dan menarik besar kemungkinan pasien kebidanan akan tertarik melahirkan di RSU Indrapura.

\section{Pinggir jalan lintas Sumatera}

Lokasi strategis UPT RSU Indrapura bisa ditingkatkan dengan membangun bagian depan rumah sakit dengan gerbang bangunan yang menarik minat masyarakat.

\section{Jumlah Keluarga Sejahtera III}

Keluarga Sejahtera III perlu disiapkan alternatif tempat pelayanan sehingga menarik minat mereka untuk menggunakan pelayanan. Rendah nya peserta bpjs di kabupaten Batu Bara (16,5\%) dari total penduduk menjadi peluang bagi UPT RSU Indrapura karena dengan memberikan pelayanan yang baik akan menarik minat masyarakat untuk menjadi peserta BPJS. Ini merupakan peluang pasar bagi RSU Indrapura untuk peningkatan pendapatan rumah sakit (Sofyan, 2003).

\section{Laju pertumbuhan PDRB Kabupaten Batu Bara}

Laju pertumbuhan PDRB Kabupaten Batu Bara menurut lapangan usaha kecendrungannya semakin meningkat termasuk di bidang jasa kesehatan dan sosial. Hal ini juga merupakan peluang besar dalam pengembangan rumah sakit karena tersedia pasar untuk produk-produk kesehatan dan pelayanan kesehatan yang lebih baik (Jakfar, 2012).

\section{Ancaman (Threat)}

\section{Fasilitas Kesehatan Di Kabupaten Batu Bara}

Fasilitas kesehatan di Kabupaten Batu Bara terdiri dari Rumah Sakit, Puskesmas, Pustu, Posyandu, Klinik/balai kesehatan, Poskesdes, Praktek dokter dan praktek Bidan. Di Kecamatan Air Putih terdapat 1 rumah sakit (Rumah Sakit Inalum), sedangkan di Kabupaten Batu Bara terdapat 3 Rumah Sakit yang menjadi pesaing UPT RSU Indrapura hal ini menunjukkan bahwa pelayanan yang diberikan oleh UPT RSU Indrapura harus berkualitas sehingga mampu bersaing (Trisnawati, 2006).

\section{Asuransi JKN}

Rendahnya cakupan peserta BPJS di Kabupaten Batu Bara Menjadi ancaman karna sekaligus mempengaruhi tingkat pendapatan UPT RSU Indrapura (Sofyan, 2003).

\section{Segmen konsumen kelompok menengah keatas}

Kelompok masyarakat menengah keatas mempunyai alternatif pilihan tempat pelayanan. Kelompok tersebut akan mempertimbangkan UPT RSU Indrapura sebagai tempat pelayanan jika mempunyai nilai jual.

\section{Angka Kematian}

Rendahnya angka kematian Ibu dan Anak di Kabupaten Batu Bara salah satu penyebabnya adalah membaiknya system pelayanan kesehatan sehingga menjadi ancaman bagi UPT RSU Indrapura jika pelayanannya lebih rendah kualitasnya dari Rumah Sakit umum yang ada di Kabupaten Batu Bara.

\section{Jumlah Sarana Kesehatan Di Kecamatan Air Putih / Kabupaten Batu Bara}

Jumlah sarana kesehatan yang tersedia menyebabkan ancaman bagi UPT RSU Indrapura karena masyarakat golongan menengah keatas mempunyai alternative pilihan yang mereka sukai, sehingga Rumah Sakit yang berkualitas akan menjadi alternative pilihan (PU, 2008).

\section{Skenario Posisi UPT RSU Indrapura}

Adapun Diagram posisi kelayakan UPT RSU Indrapura digambarkan dalam matrik analisis SWOT yang ditunjukkan pada gambar berikut.

Tabel 1. Matrik SWOT

\begin{tabular}{|l|l|l|}
\hline & Oppurtunity & Threat \\
Strenght & Kuadran I (SO) & Kuadran III (ST) \\
Weakness & Kuadran II (WO) & Kuadran IV (WT) \\
\hline
\end{tabular}

Hasil diagram kelayakan adalah sebagai berikut:

1. Kuadran I : $\mathrm{SO}=3,8 \times 1,8=6,84$

2. Kuadran II : $\mathrm{WO}=2,4 \times 1,8=4,32$

3. Kuadran III : ST $=3,8 \times 2,5=9,50$

4. Kuadran IV : WT $=2,4 \times 2,5=6$

Fakta diatas menunjukkan bahwa UPT RSU indrapura berada di Kuadran 111 hal ini berarti: UPT RSU Indrapura layak dikembangkan, Dengan rekomendasi :

1. Memperkuat Kekuatan

2. Mendapatkan Peluang 


\section{SIMPULAN}

Studi kelayakan adalah untuk menentukan kelayakan suatu proyek, dalam hal ini untuk mengetahui tingkat kelayakan pengembangan UPT RSU Indrapura. Dalam prosesnya terdapat beberapa aspek yang dinilai diantaranya kelayakan dari aspek lokasi keberadaan UPT RSU Indrapura, berdasarkan kebutuhan pelayanan/pasar, berdasarkan hukum dan sarana, aspek persaingan, aspek ekonomi. Dari peninjauan berbagai aspek diatas UPT RSU Indrapura layak diteruskan. Keberhasilan UPT RSU Indrapura ditentukan oleh Komitmen SDM dokter yang melayani dan pelayanan yang diberikan harus meimliliki kelebihan dari segi mutu, sehingga pelanggan diharapkan bukan dari sekitar Indrapura tetapi masyarakat dari luar Kabupaten Batu Bara. Keberhasilan juga ditentukan oleh upaya memperbaiki faktor kekuatan dan untuk mengurangi ancaman.

\section{DAFTAR PUSTAKA}

Alamsyah, D. (2011). Manajemen Pelayanan Kesehatan. Yogyakarta: Nuha Medika.

Jakfar, K. d. (2012), tudi Kelayakan Bisnis, Edisi Revisi. Jakarta: Kencana.

Kementrian Kesehatan Republik Indonesia, D. B. (2012). Penyusunan Studi Kelayakan (Feasibility Study) Rumah Sakit. Jakarta: Kementrian Kesehatan Republik Indonesia, Direktorat Bina Pelayanan Penunjang Medik dan Sarana Kesehatan, Direktorat Bina Upaya Kesehatan .

LPPM. (1994). Pegangan Gaya Penulisan, Penyuntingan, dan Penerbitan Karya Ilmiah. Jakarta: Depdikbub, Ditjen Dikti.

Meriam, J., \& Kraige, L. (1988). Mekanika Teknik Statika (Jilid I, Versi SI). (terjemahan Tony Mulia). . Jakarta: Erlangga.

Rangkuti. (2013). Analisis SWOT teknik membedah kasus bisnis, cara perhitungan bobot, rating, dan OCAI. Jakarta: PT Gramedia Pustaka Utama.

Republik Indonesia, 2014a, Peraturan Menteri Kesehatan Republik Indonesia Nomor 56 Tahun 2014 tentang Klasifikasi dan Perizinan Rumah Sakit, Jakarta.

Sofyan. (2003). Studi Kelayakan Bisnis. Edisi Pertama. Yogyakarta : Graha Ilmu.

Sutojo, S. (2002). Studi Kelayakan Proyek : Konsep, Teknik dan Kasus. Edisi Baru. Jakarta: PT. Damar Mulia Pustaka.

Trisnawati, E. (2006). Pengantar Manajemen. Jakarta: Kencana.

PU, K. (2008). Permen PU No. 16/ PRT/ M/ 2008 tentang Kebijakan dan Strategi Nasional Pengembangan Sistem Pengolah Air Limbah Pemukiman. Jakarta: Kemen PU. 